\title{
PORTRAITS AND FIGURATIVE PAINTINGS OF JAHANGIR'S ERA
}

\author{
Dr.Drashti Jaykrushna
}

\begin{abstract}
:
Jahangir's school of painting is a treasure in itself. It was a golden period of miniature paintings in Indian art. Very famous painters of Jahangir's court like Abul al Hasan, Mansoor, Bichitra, Govardhan, Bisandas painted famous court paintings, paintings of birds and animals, flora and fauna so brilliantly. In this paper I emphasize how figurative composition and portrait details were drawn in Jahangir's paintings.
\end{abstract}

Keywords: Mughal Paintings, Persian, Indian style, paintings, Mughal emperors, Akbarnama, Indian portraiture, European traditions, portrait, landscapes, masterpiece, historical illustrations, transformed, Mughal masterpiece, characteristic, Mughal sketches, figural mass, non-political subjects, Museum in New York, iconographically.

Mughal Paintings form a blend of the Persian and Indian style. The paintings of the Jahangir era depicted several themes. The paintings of that period were rich in their range and included events, portraits, hunting scenes, wild life, instances of battles etc. Most early Mughal portraits are of male courtiers, since females were rarely permitted to appear in open courts. It was due perhaps to the influence of Noor Jahan, the favourite queen of Jahangir, that women became more popular as the subject matter of painting. Bichitra was one of the most brilliant Mughal portrait painters, who was active under both Jahangir and Shah Jahan. Bichitra's portraits are admirable for their refinement as well as their subtle characterizations and these two sensitively rendered miniatures are among his finest works.

After Akbar, Jahangir encouraged artists to paint portraitsand durbar scenes. His most talented portrait painters were Ustad Mansur, Abul Hasan and Bishandas. The painter Mansur received an imperial title for his depictions of animals and flowers. Others were known for their portrait work, allegorical pictures or beautiful illuminated borders. In the 1700, scenes featuring pretty women at various activities became fashionable.1

The portraits are, first of all, hugely diverse, varying in subject matter, size, style and technique. They range from scenes of court life to individual portraits which depict Mughal emperors, courtiers and holy men, as well as women and Europeans living in India. The first Indian portraits date to the reign of the third Mughal emperor Akbar (r. 1556-1605), who commissioned a series of portraits both of himself and of his courtiers. Abu'lFazl, the 
historian of Akbar's reign, recorded this innovation in Mughal court painting in his chronicle the Akbarnama: 'portraits [surat] have been painted of all His Majesty's servants, and a huge book [ketab] has been made'. Shah Jahan commissioned a similar 'official manuscript' of his reign, the Padshahnama ('The Book of the Emperor'), which features 44 illustrations depicting events from his life. Another grandiose official portrait is the six-foot life-size image dating to 1617 of the fourth Emperor Jahangir holding a globe, which is believed to be the largest painting to come from the Mughal Empire.

However, the display also provides more intimate glimpses of the Mughal emperors, as well as moving insights into the lives of their courtiers. Alongside the stylised images of Akbar presented in the Akbarnama, for example, there is also a simple black and white ink drawing of the emperor which captures his mood and personality. Particularly sombre and moving are the drawing and accompanying finished painting of 'Inayat Khan, one of Jahangir's attendants, in his last days. The portrait was commissioned by Jahangir who recorded in his memoirs on October 10th, 1618, that 'Inayat Khan 'was addicted to opium, and when he had the chance, to drinking as well [...] He appeared so low and weak that I was astonished... As it was a very extraordinary case, I directed painters to take his portrait'.It also reveals the evolution of Indian portraiture over three centuries, its richness and its complexity; it both influenced art in regions which gradually fell under Mughal control and was, in turn, influenced by European and British traditions. Art in the Deccan sultanates, which included the five Islamic kingdoms of Ahmadnagar, Berar, Bidar, Bijapur and Golconda on the Deccan Plateau in south-central India, became increasingly influenced by Mughal traditions as the region was conquered by the Mughal emperors from 1596 to 1686 . The sultans increasingly commissioned portraits of themselves similar to those of the Mughal emperors. By 1614, the independent Hindu Rajput kingdoms of Rajasthan and the Hill (Pahari) region north of Delhi had also been incorporated into Mughal territory. The conquered kingdoms similarly absorbed aspects of Mughal culture, which is reflected in portraits of time such as that of Kunwar ('prince') Anop Singh of the principality of Devgarh in the powerful Mewar kingdom riding with a falcon.

But Indian portraiture was also influenced by British and European traditions and increasingly so in the 18th and 19th centuries as India came under British control. A portrait of Jahangir triumphing over poverty believed to date to 1625 reveals, for example, how Indian portraiture increasingly came to incorporate elements of western art: two European cherubs are placing a crown on the emperor's head, whilst a third is handing him the arrows which he is using to kill poverty. During the British period, Indian artists were employed to produce paintings of local scenes and people and some also received patronage from employees in the East India Company. Portraits from this period include a curious and amusing depiction of William Fullerton (c.1725-1805), a surgeon with the East India Company, who is portrayed in a totally Indian way reclining against a bolster on a terrace and smoking a huqqa.2

\section{Figure -1 Nurjahan}




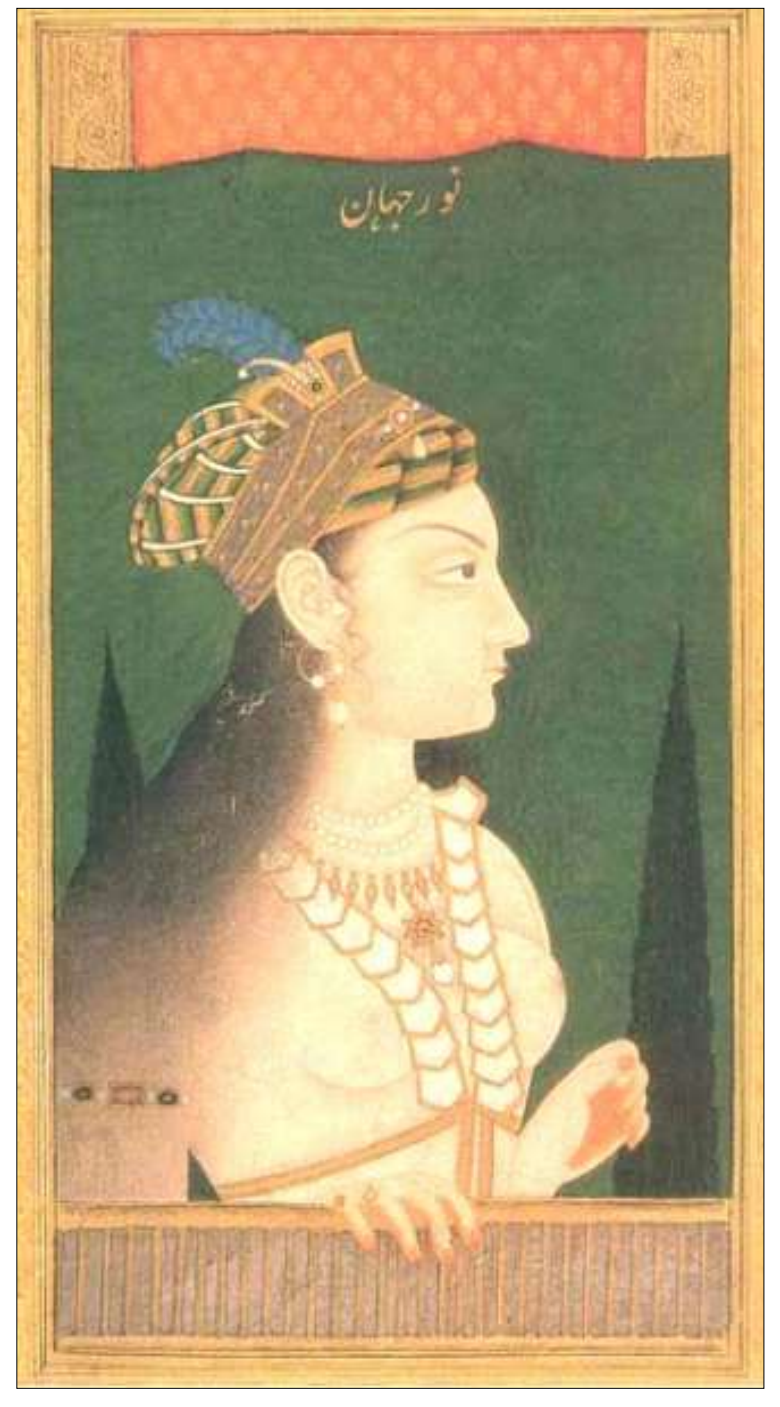

the arts, especially miniature painting.

\section{Figure- 1}

Nurjahanhttp://guity-

novin.blogspot.in/2010/02/history-ofgraphic-design-art-of.html
Female portraits were allowed during the Jahangir's reign, in spite of the fact that his Muslim father Akbar did not favor it. His queen, Nur jahan, is the subject of this masterpiece of circa 1740-1750. In 1611, Jahangir married Nur Jahan, the widowed daughter of a Persian immigrant. She and her relatives soon dominated politics, while Jahangir devoted himself to cultivation of

The stylistic emphasis of Indian Miniature shifted towards greater realism in landscapes and portrays in its second phase during the Jahangir reign (1605 - 1627). Jahangir's love of miniatures was developed years before he ascended to the throne during which, under the Persian painters Aqa Riza and his son Abu Hasan he set up his independent studio at Allahabad. The work of various artists in Jahangir's court such as Abu Hasan's court scenes and official portraits, Mansur's landscapes and historical illustrations, and Daulat's portraits as well as others were influenced by the Persian style of Aqa Riza, with the flat surfaces and highly embellished. The female portraitures of this era reveal a sophisticated compositional execution.3

\section{Figure-2, Jahangir as the Queller of Rebellion, Ca. 1623 Inscribed: Abu'l - Hasan}

Here one of Jahangir's most painful disappointments has been transformed into a superb miniature by Abu'l - Hasan, a favourite imperial artist. In 1618 Jahangir wrote, "At the present time (Abu'l - Hasan) has no rival or equal. If at this day the masters 'Abdu-1-Hayy and Bihzad were alive, they would have done him justice. His father, AqaRiza'i of Herat,at 
the time when i was prince joined my service. He (Abu'l Hasan) was a khanazad of my court. There is, however, no comparison between his work and that of his father (i.e., he is far better than his father). One cannot put them into the same category. My connection was based on my having reared him from his earliest years up to the present time I have always looked after him, till his art has arrived at this rank. Truly he has become Nadir-i-zaman ("the wonder of the age")."

Abu'l-Hasan was as adept at portraiture, bird and animal studies, still life's, and landscapes as at architectural scenes seething with figures. In this pictorial fantasy the emperor is

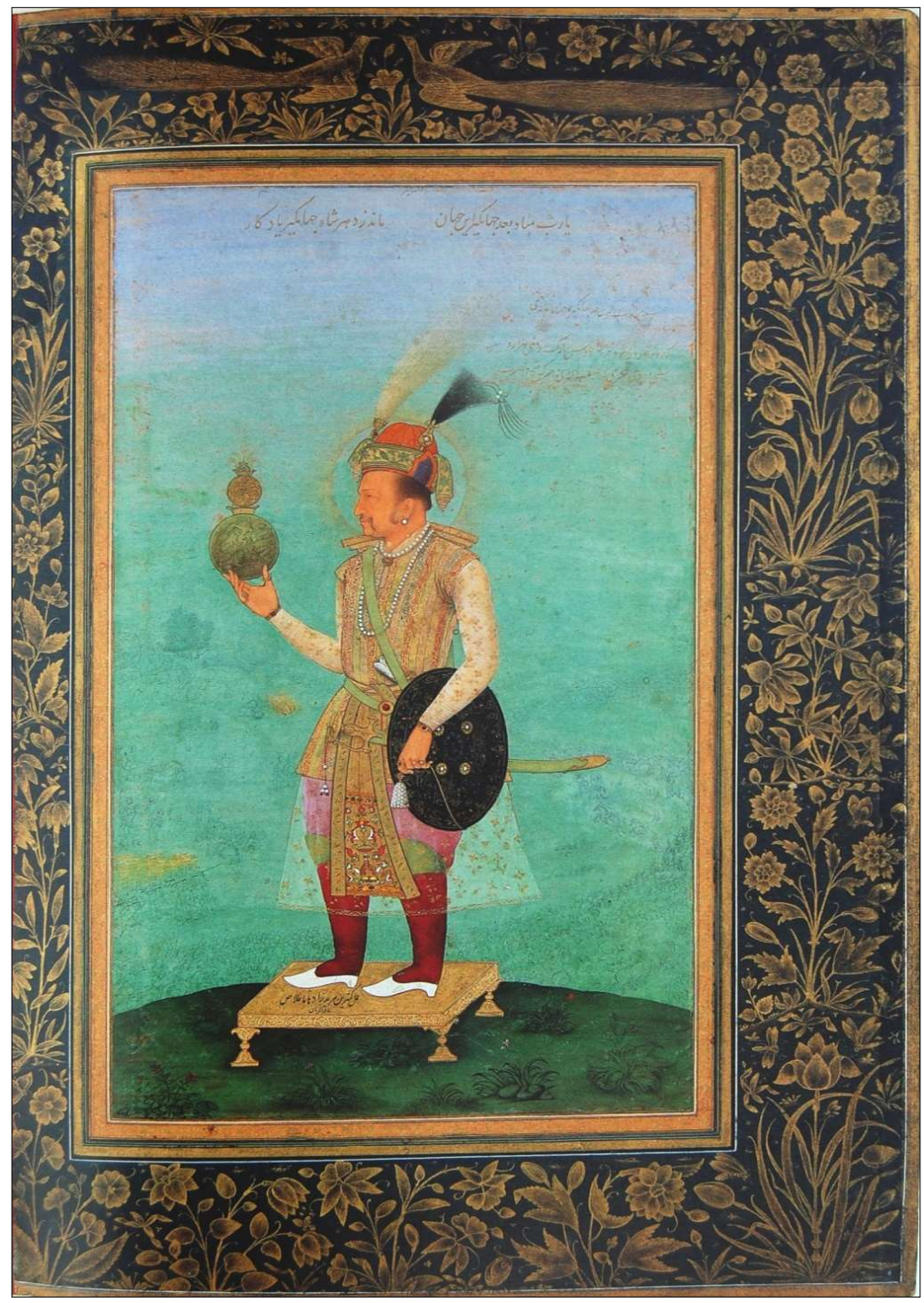

portrayed victoriously, on quelling in 1623 the rebellion of his once-favourite son, prince shahjahan ---henceforth known to him as be - daulat (wretch). His haloed visage expresses omnipotence touched with sorrow and disdain as he surveys the plain below,

Figure 2 Jahangir as the Queller of Rebellion, Ca. 1623 Inscribed: Abu'l Hasan, (Edi. Stuart Cary Welch, Annemarie Schimmel, Marie L. Swietochowski, Wheeler M. Thackston, The Emperors' Album Images of Mughal India, 1988, page105.)

Where the imperial army led by Mahabat Khanquashes the rebels. In keeping with the meaning of Jahangir's name (world Seizer), he elevates a globe surmounted by the royal seal, which in turn sports a plumed crown, a symbolic creation of utmost artifice, as though it were 
weightless. To raise him from the mere earth of a flower- tufted hilltop, the emperor stands on a golden taboret worked on relief.

Jahangir's costume is Mughal masterpiece. Its massive pearls, black and white plumes, harness, weapons, wine-colored leggings, nubby white shoes, sash and flaring collars proclaim the wearer's imperial glory. Each sumptuous part-from the black buffalo-skin buckler, adorned with horsemen and footsoldiers drawn in gold, to the orange and gold helmet with blue earflaps - harmonizes so rapturously with the ensemble that one wonders if Abu'l-Hasan did not design as well as paint them. No better garb could be devised for viewing footsoldiers and cavalry, frantic as battling ants.

Abu'l- Hasan's artistic personality was shaped by Jahangir's guidance, by his father's Iranian training, by his study of engravings by Durer and by Flemish Mannerists, and most of all by his extraordinary sensitivity to the visual world. As a boy of thirteen in 1600, he drew a remarkable Saint John taken from a print by Durer. But simultaneously he was working in the vigorous Mughal style of Akbar's court, as can be seen in his brilliant Bullock Cart, which blends Akbar's powerful idiom and the subtle fineness admired by Jahangir.

Abu'l - Hasan's close involvement with the imperial court provided him with a unique education. Not only did he observe the kaleidoscopic dramas and comedies of Mughal India from the very center, but he also heard the conversations of wits and sages. On the evidence of his illustrations to such Iranian classics as Sa'di's Bustan (Garden) and the Anwar-iSuhayli (Lights of Canopus) he was also perceptive reader. His pictures, more than those of any other Mughal artist,reflect the totality of imperial thought and life. Unsurpassed as characterizations, his studies of holy men are as serious and provocative as Govardhan's. But he could also capture an infant's changes of mood from irritation to delight and satirize a petty official's eye-popping outrage.

Abu'l- hasan was so loyally devoted to Jahangir that his portraits of Shahjahan usually show him as a bedaulat rather than than as the favourite prince. Although his brother 'Abid painted at least four miniatures for the Windsor Padshahnama, signing one of them as the "Brother of Nadir az-zaman of Mashhad," Abu'l-Hasan is not represented in that manuscript. Barely forty years old at the time of Shahjahan's enthronement, he remained Jahangir's artist.

This verso painting has the margin number 8; it therefore belongs to Group B. It has no cutout poetry around it and no inner border of the usual sort. Its outer border contains flowering plants in gold on a blue ground (neither the plants here nor those on the recto of this leaf are identifiable), with a pair of fancifully rendered birds, which should traditionally be birds of paradise, above the emperor.

An early nineteenth-century copy of this painting was auctioned at Sotheby's on October 14, 1980, lot 193, illustrated. Unfortunately, none of the borders of the group of later copies of seventeenth-century portraits in the Kevorkian Album has been included in the illustrations, so whether or not the border schemes were also copied cannot be confirmed. 4 
Figure-3. Jahangir stands against a dark background framed by a halo with gold rays holding out a globe with an escutcheon plate and key in his right hand. He wears a red turban; necklaces and bracelets of pearls, rubies and emeralds; and an elaborate patka. A sword, dagger and archer's rings are also at his waist (illustrated).

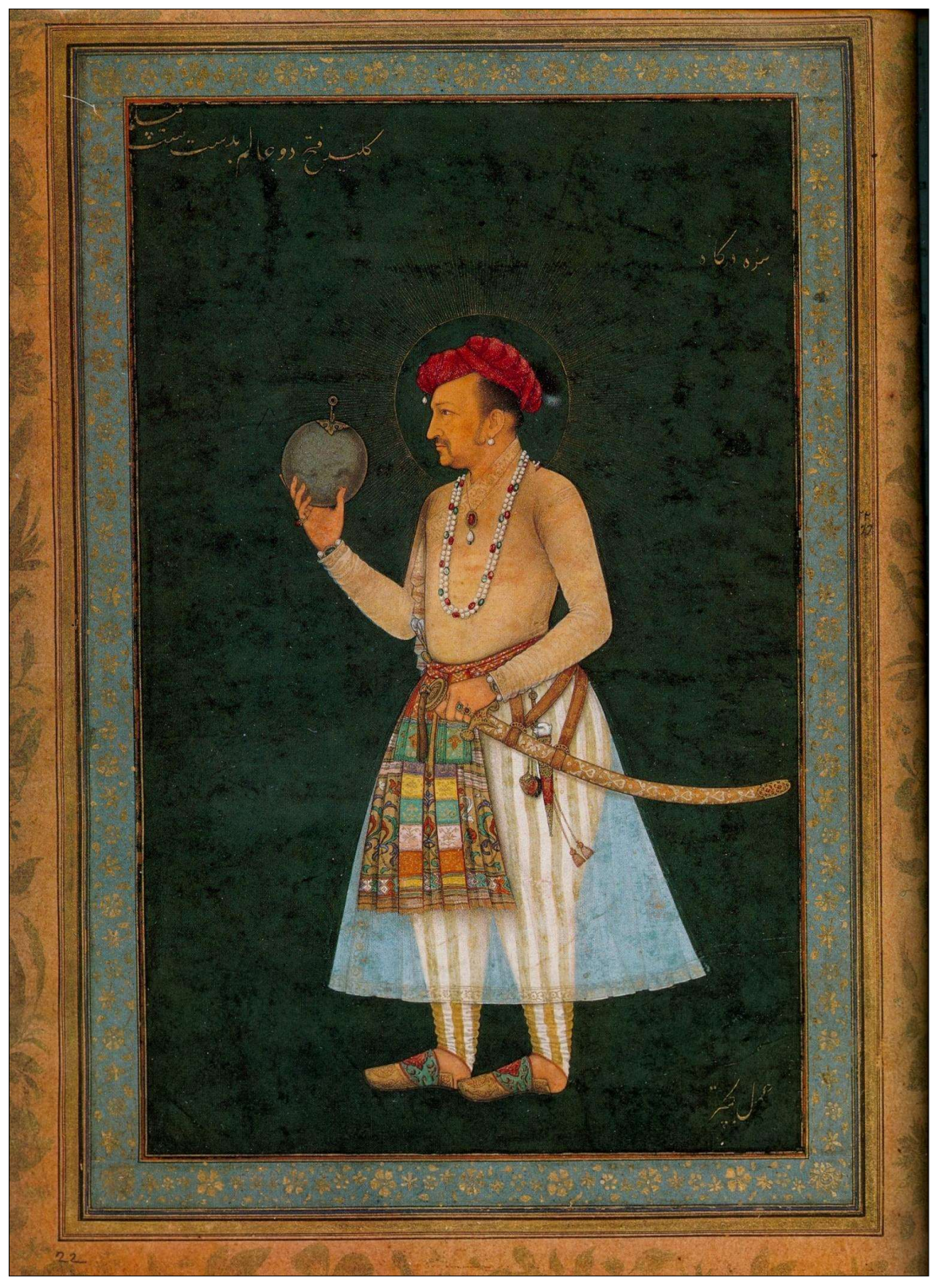

Figure-3 By Bichitr, c. 1620, Verso (edi. Linda York Leach, Mughal and other paintings from the chesterbeatty library volume-I, 1995, page387)

Inscriptions: inscribed on the margin with the folio number 22; three inscriptions in gold appear on the painting; that in the lower right reads: 'amal-ibichitr ('the work of Bichitr'); the two notes in the upper section of the miniature read: top left kalid-ifath-idau'alam bi-dastast (musallam) ('the key to the conquest of both worlds is entrusted to your hand'), and top right (?) banda-yi dargah ('slave of the court')

Borders: pale blue inner border, outer pink with gold flowering plants, size: $20.5 \times 12.7 \mathrm{~cm}$

Reverse: inner border pink, outer dark blue ornamented with floral scrolls and medallions frames verses by 'Ali al Katib al-sultani (the sultan's scribe (Mir) 'Ali), Library number: 7A.5 Reproduced: Arnold and Wilkinson, pl. 57; Das, 1978, pl.1. 
Note: This miniature showing the Emperor Jahangir holding a globe with a key inserted into a lock was once half of a double page allegorical composition that alluded to the emperor's reception of spiritual and temporal knowledge. It seems originally to have been placed opposite a depiction of the sufi saint sheikh Mu'in al-Din Chishti, also by the artist Bichitr (c5 figure-14). The twelfth-century saint, who established the chishti order in India in the city of Ajmer, is shown holding out the same globe that appears in this miniature with the key topped by the Timurid crown.

The Significant explanatory verse inscribed on this portrait alludes to a key that could open the two worlds, material and spiritual, and was at the behest of the chishti founder. Jahangir's interest in such symbolism correlates with the faith he maintained through his life in various ascetics and holy men whom he believed could provide him with unique psychological guidance. The association of the globe and keyhole with the Chishti sect probably captured Jahangir's fancy during the years from 1613 to 1616, when he located his court at Ajmer and was closely involved in the activities of the sufis there. A further miniature showing Jahangir with a key in his belt and his feet placed upon a globe with a keyhole is recorded as actually being produced at Ajmer. Because the conceit of globe with the keyhole is one that pleased the emperor, it was frequently used during his reign. The Timurid crown indicates Jahangir's assumption of the successful empire founded by the heroic Timur, who was unlike himself but a legendary subject of admiration. To see himself as heir to the Persian cultural tradition with his sovereignty under the auspicious guidance of Islam was much more important to Jahangir than it would have been to Akbar; Akbar in fact actively sought to distance himself from influences that his son reaffirmed in this and other state portraits.

Milo Beach has ascribed this page and the facing composition to the period of 1635-40; however, there is no reason to doubt a during Jahangir's lifetime nor to question that the two miniature are among the artist Bichitr's earlier extant works. The precise style and finish of these works is typical of the late Jahangiri era, but it is even more significant that the symbolism of the two pictures is characteristically Jahangir's.

Shah Jahan also had himself portrayed receiving the key to knowledge from Mu'in al-Din Chishti in his biographical Padshah Nama. In 1631/2, his fortieth year, this emperor requested Bichitr to paint portrait of him with hands outstretched which was then mounted across from Bichitr's earlier depiction of Mu'in al-Din. Folio numbers, border colours and miniature style agree so that the pair is quite certain. Apparently, Shah agree so that the pair is quite certain. Apparently, Shah Jahan must therefore have had his father's portrait removed from its place opposite the Chishti saint and remounted next to some other now unknown work in the royal albums.

Bichitr's style in both this portrait of Jahangir and the depiction of Mu'in al-Din Chishti is cool and controlled. It is also somewhat two-dimensional, focusing on decorative details such as the emperor's elaborate patka. Bichitr is notable for his ability to render such effects with an intensity that gives the impression of viewing surfaces under a magnifying glass. Although nothing is known of his arrival at court, Bichitr had become one of Jahangir's influential painters by about 1616. Along with the emperor's favourite miniaturist Abu'l-Hasan, who 
was a Muslim, Bichitr, a Hindu, produced the allegorical works which often included rather esoteric references to Islam and were characteristic of the emperor's late commissions. The calligraphy on the backs of Minto miniatures is almost all by the late fifteenth and sixteenth century Mir'Ali, who signs the passages in a variety of ways. Here he has called himself the sultan's scribe, but more often he terms himself 'this poor man'. $\mathbf{5}$

figure-4.1 \&4.2 A Muslim saint in white with a shawl around his shoulders stands holding a large globe in both hands. Above the globe, which has a keyhole, is suspended a red cap-like crown with jewels topped by a feather. The halo of the saint emits gold rays onto a black ground (illustrated)

By Bichitr, ca.1620, Recto

Inscriptions: folio number 52 on the margin. The painting also has three inscriptions in gold. The one in the upper right reads: banda-yi dargah ('slave of the court'); the one on the globe reads kalid-ifath-idau 'alam bi-dast-itustmusallam ('the key to the conquest of the two worlds is entrusted to your hand'); the inscription below reads raqam-ibichitr ('work of Bichitr') borders: inner border pink, outer buff with multi-coloured flowering plants. Size: $21.8 \mathrm{x}$ $13 \mathrm{~cm}$, Reverse: inner border pinls, outer buff with multi-coloured flowering plants surrounding calligraphy by Mir 'Ali. Library number: 7A. 14

Reproduced: Arnold and Wilkinson, I: frontispiece; Wilkinson, 1949,p.1.8; Gascoigne, p.61.

Note: In Arnold and Wilkinson's earlier catalogue, this portrait was mistakenly identified as the sage shah Daulat, though a very different depiction inscribed as this man was also in the collection. Bichitr's subject has now been established as Mu'in al-Din Chishti, the twelfth century founder of the Chishti order of sufis in India; the identification is based on a folio in the Windsor Padshah Nama showing Mu'in al-Din presenting a globe to Shah Jahan with the Chishti shrine at Ajmer evident in the background. Mu'in al-Din Chishti is credited with bestowing legitimacy as well as the dominion of knowledge upon the Mughal lineage largely

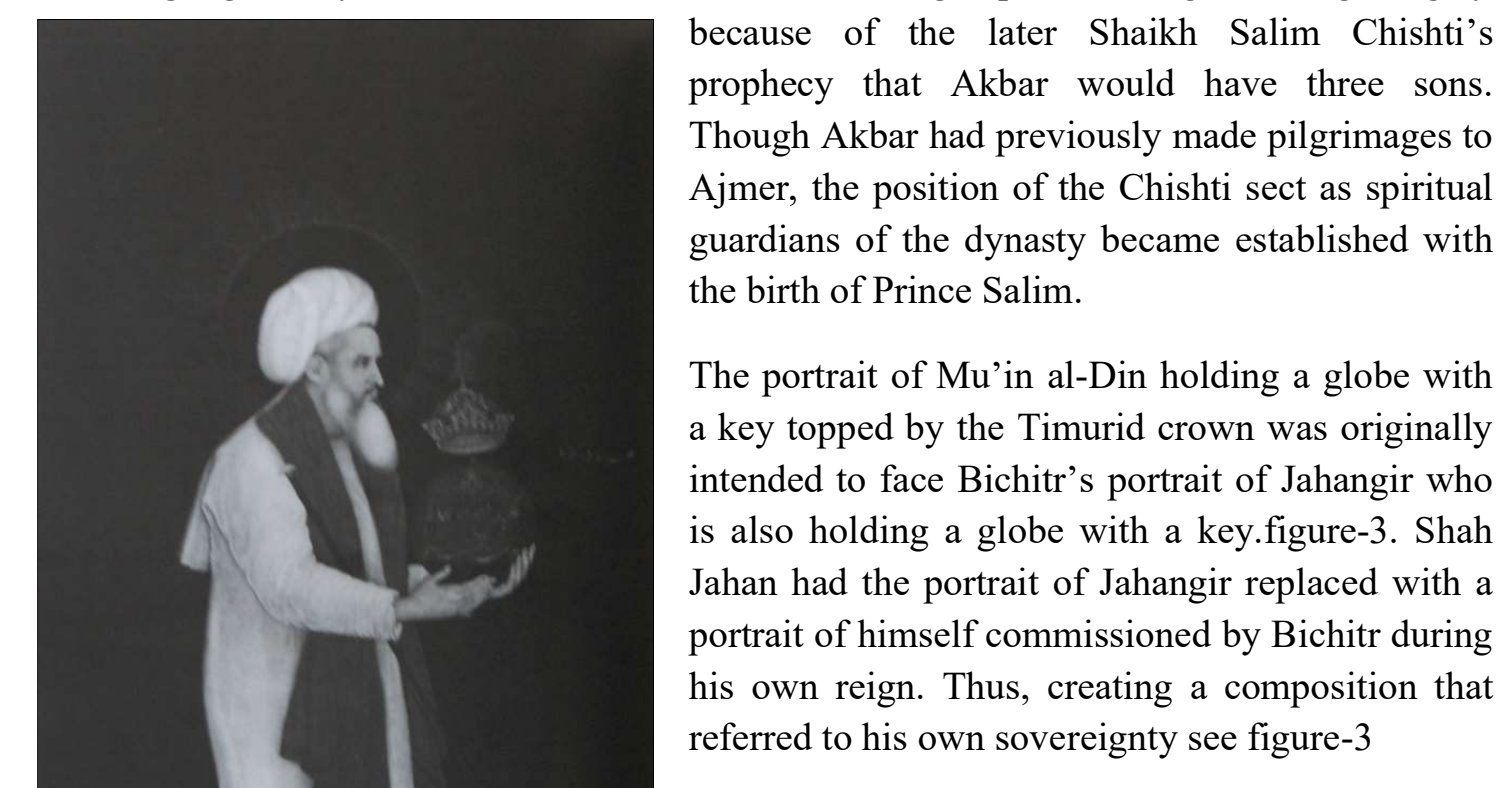

//hrdc.gujaratuniversity.ac.in/Publication $\quad$ Page | 399 
Figure-4.1

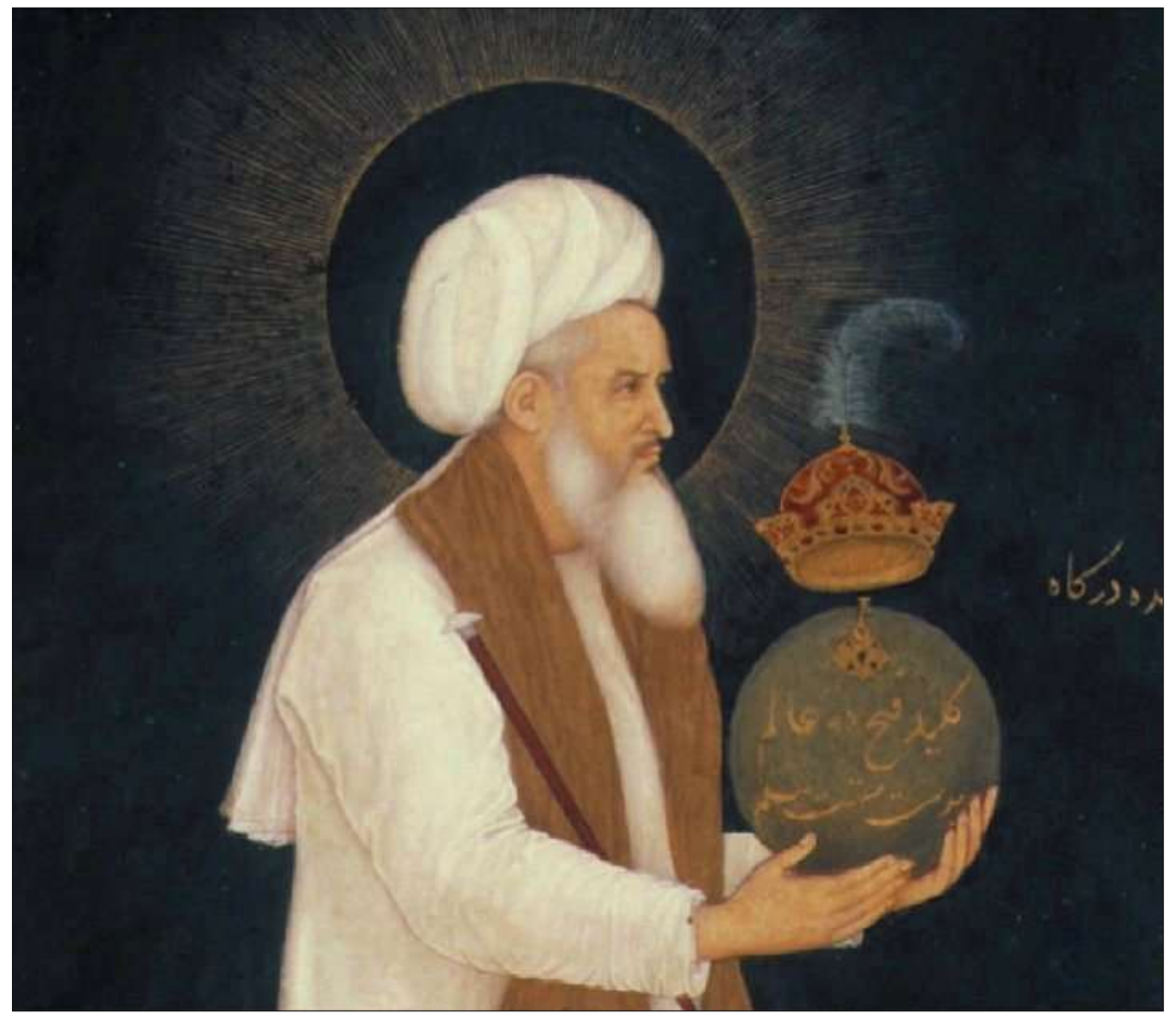

Figure-4.2

(edi. Linda

York Leach,

Mughal and

other paintings

from the

chesterbeatty

library volume-

I, 1995, page-

386) The most

notable aspect of

Bichitr's

depiction is that

the artist has

created a

naturalistic

likeness for the long-dead,

legendary Mu'in al-Din. The long nose, turned down mouth, and jutting brows all indicate an extremely specific characterization. Such forceful assertion of personality does not always occur in Bichitr's scenes since the artist often became absorbed by the purely physical rendering of features or details of costume, rather than in suggesting the psychological through them; for example, the portrait of Jahangir that originally faced this miniature figure3 is a bland image as are the figures in Bichitr's group portrait of Akbar,Jahangir and Shah Jahan. The representation of Mu'in al-Din is more akin to Bichitr's animated depiction of Muhammad Riza Kashmiri, also a Muslim religious figure. Seemingly the painter felt freer to express himself in doing non-political subjects and, although he was a Hindu, had become astute at capturing Muslim characteristics.6

Figure-5 The face of a pensive young man is captured in profile. He wears a high turban wrapped in an uncommon style and leans forward with an absorbed expression (illustrated). 
c.1615, Brush drawing, Size: 5.7x5.2cm, Library number:55.6b

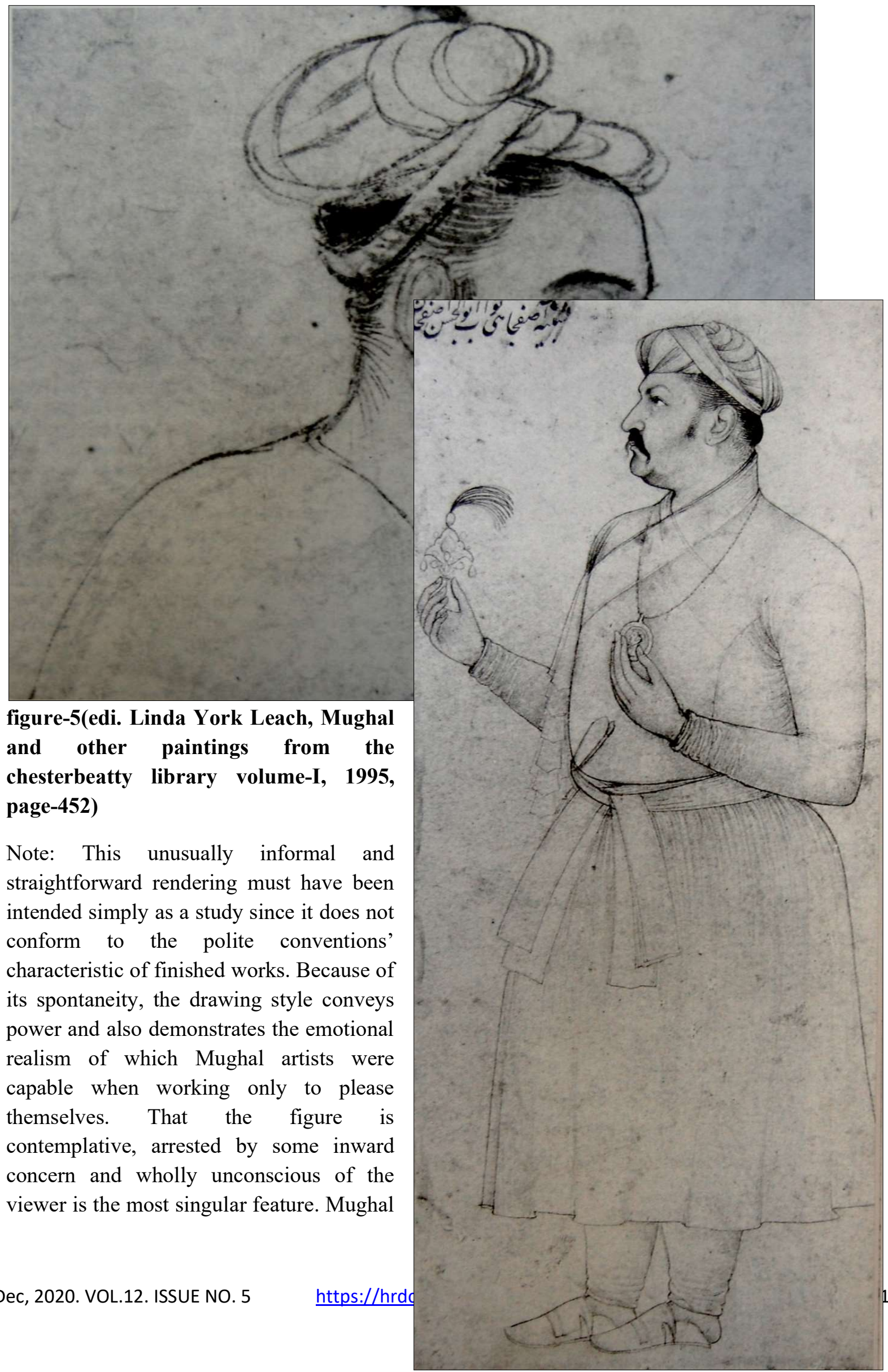


portrait subjects were generally posed self-consciously with an indeterminate expression that, perhaps defensively, does not reveal anything to the onlooker. Such blankness functioned as the 'correct' standard of dignity and courtly nobility. Early Mughal sketches are rare, but a portrait head of Akbar and another of Shah 'Abbas in styles that differ from this study make instructive comparisons. The young man's turban is oddly wound, but piled bands pushed toward the back of the head are occasionally seen in miniatures of either Akbar or Jahangir's era.7

Figure-6, The courtier Asaf Khan holds a sarpech: in one hand and with the other touches a circular miniature of Jahangir worn around his neck. He is depicted as a strong, heavy man of middle age with a long moustache (illustrated).

c.Brush Drawing Inscription: shabih-iasafjahi-yinavvababu'l-hasanasaf khan ('likeness with the dignity of Nawab Abu'i-Hasan Asaf Khan') size: 16x17.5cm, library number: 45.2

\section{figure-6( edi. Linda York Leach, Mughal and other paintings from the chesterbeatty library volume-I, 1995, page-453).}

Note: Abu'l-Hasan, title Asaf Khan in 1614, was Jahangir's brother-in-law and hence an exceptionally influential courtier during the period when this drawing was made. Near the end of Jahangir's reign, he succeeded his father, I'timad al-Daula, as vizier. He had also previously married his daughter Mumtaz Mahal so Shah Jahan, and when this prince bested his brothers and was crowned emperor, Asaf Khan was promoted to ranks that position and wealth were therefore almost unsurpassed during the majority of two reigns when he was continually depicted by the best painters.

This is certainly one of the finest, though not one of the most opulent, portraits of the khan. It is an elegant, consciously designed drawing that was never intended simply as a sketch. The drawing line is tense and dynamic so that even though the subject himself stands placidly; he nevertheless seems very much alive. In contrast to other, somewhat bland, official portraits of Asaf Khan, this comparatively early portrayal accentuates his rugged features and heavy face so that a particular characterization emerges. He appears the intelligent, remarkably shrewd courtier he undoubtedly must have been in order to maintain his position at an intrigue-filled court. Asaf is noted by chroniclers for his accounting ability which helped him keep personally abreast of event as a minister and prevented corruption. The artist has captured both his subjects' toughness and his acuity.

The aristocrat is mentioned for the first time in Jahangir's diary during the year 1611 when he received his earliest imperial title and his sister married the emperor, which must have greatly accentuated his personal rise; he was then aged forty-two. Portraits of him commence at this time and were produced for approximately thirty years thereafter, so that it is instructive to survey the Beatty drawing in context. There are several works illustrating events prior to the execution of the Beatty scene which include Asaf Khan within a group. The first, done 
around 1611, shows him in a polo game with the emperor and princes, registering the khan's intimacy with the imperial family. Two larger scenes are recreations purporting to show Asaf Khan as he looked in 1607 and 1609. These two depictions offer an interesting contrast to the Beatty drawing as they demonstrate how artists generalized their subjects in such circumstances, presenting a far less trenchant or personal image derived from a file of sketches.

The accomplished style of the Beatty drawing, the confident illusion of figural mass created, and the age of Asaf Khan all suggest that it was done around 1615. Two much less naturalistic or proficiently executed single standing portraits may predate the Beatty miniature; they appear to have been produced respectively around 1611 and from the period of 1611 to about 1615 . The Beatty drawing seems to be the earliest surviving single portrait by a top-quality artist.

Asaf aged slowly and hence it difficult to arrange his numerous likenesses in chronological order. In his late forties he probably acquired a beard, however, that appears in all portraits thereafter. This feature distinguishes the Beatty drawing from a depiction by Balchand that might otherwise appear contemporary or even somewhat earlier. A further picture of Asaf Khan acting as commander-in-chief during the year 1630/1 shows him only slightly changed with the passage of years as do other late images. The khan died in 1641 at the age of seventy-two.

The Beatty drawing shows Asaf Khan calling attention to the portrait miniature hung around his neck. The custom of wearing such miniatures was initiated by Jahangir who delighted in giving them to nobles, ostensibly to demonstrate his fondness for particular courtiers but in reality, because he enjoyed seeing his own image as a proof of dependence. Although the Beatty drawing is by an artist who is easily of imperial stature, the possibility of Asaf khan commissioning this portrait as a gift for Jahangir should not be ignored. As was the case with other favours, the khan imperial portrait miniature and may have been providing the evermistrustful sovereign with an indication of his appreciation as well as his continuing loyalty. Perhaps the two standing portraits that predate the Beatty example but are of lesser quality were also Asaf Khan's commissions to his own artists.

Asaf Khan has been recorded as a patron of painting and is known to have lived in a very luxurious style. In his memoirs Jahangir comments that he was impressed by the extensive gardens and estates of Asaf Khan which he visited. The Maathir-ul-umara says, 'the expenses and disbursements of his establishment were beyond comprehension, especially those... incurred for the frequent visits to him of the king, the princes and the begams. The biography especially notes the extravagant gifts, the feasting, and the decoration. Although no documentation exists, the khan's exalted position and the tenor of his lifestyle intimate that his artists could well have been very skilled.8

Figure-7 the Emperor Jahangir stands posed against a pale green background holding a sword and rosary. He wears a purple turban with a string of jewels across it and several strands turban with a string of jewels across it and several strands of pearls, emeralds, 
emeralds and rubies. At his waist are a dagger and several archer's rings. A short tiedyed patka hangs over a more elaborate gold-flwered one (colour plate).

By Balchand c.1620, Inscription: at the base of the miniature 'Balchand', size: $18 \times 19.2 \mathrm{~cm}$, Library number:45.1.

Note: This is one of many full-length standing portraits of Jahangir that must have been produced during his reign; however, most now survive only in either sub-imperial or later copies. This sumptuous depiction inscribed to a foremost imperial artist is therefore a rare example of the rich but restrained type so characteristic of the period. The emperor is clad in simple white, but his jewellery is exceedingly opulent. The treatment of the two patkas with their contrasting patterns is subtle yet underlines the conscious awareness of design conspicuous among Jahangir's miniaturists.

Figure-7(edi. Linda York Leach, Mughal and other paintings from the chesterbeatty library volumeI, 1995, page-467)

Balchand was an artist whose career extended from the late Akbari period well into Shah Jahan's reign. His work begins with quite stylized, pretty figures and culmininates in complex, naturalistic crowd scenes illustrating shah Jahan's biography. In between, his productions move between stylization and naturalism. A beatty portrait of Shah Jahan and his sons done approximately ten years after this scene, for example, is much flatness in this depiction of Jahangir. A portrait by Balchand of the minister Asaf Khan in the Wantage Album, consistent with the style of this painting and approximately

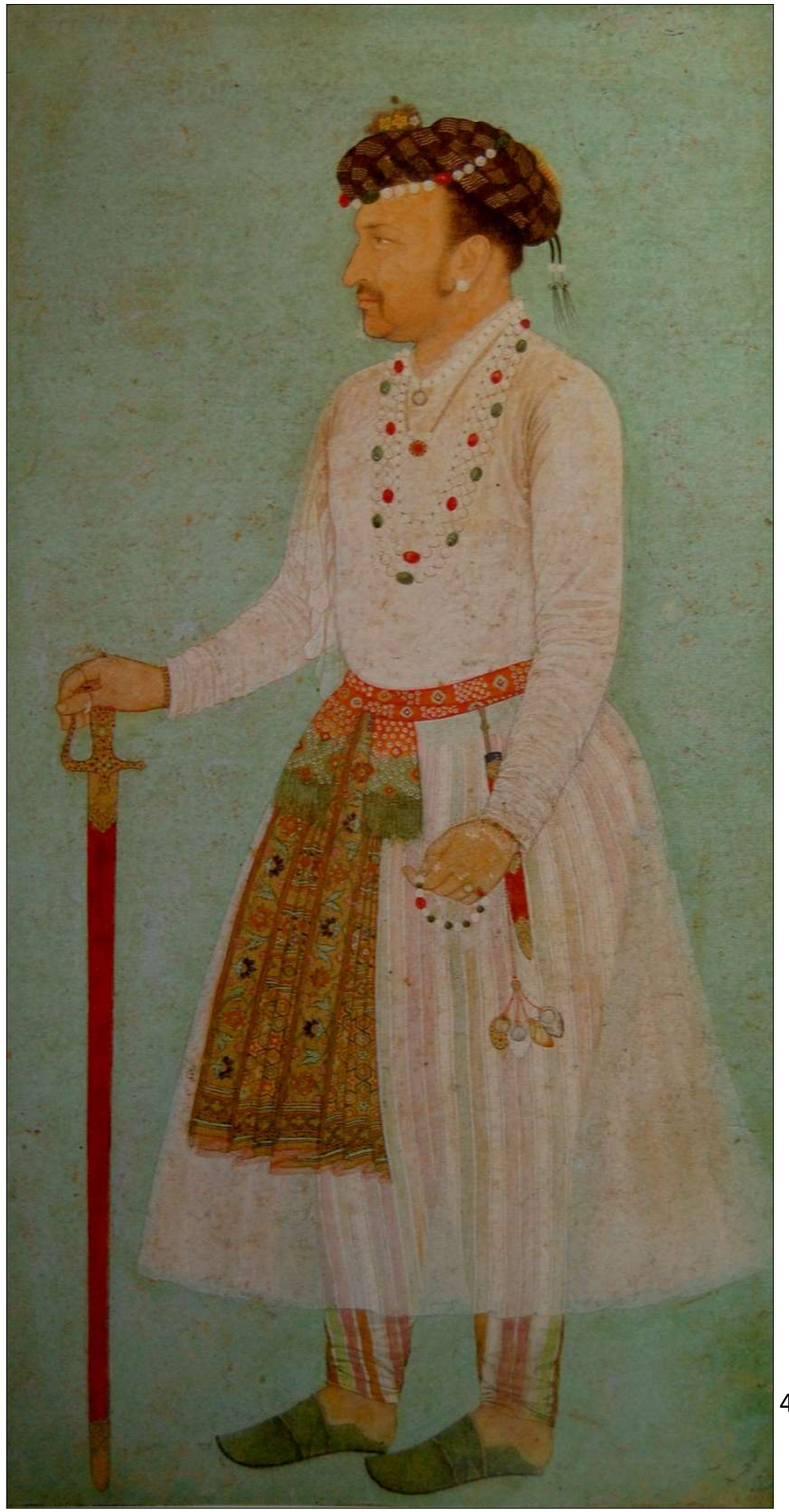


contemporary, is perhaps the closest example of Balchand's artistry.

Standing portrait drawing of Jahangir that that make apt comparisons with this depiction but were done nearer the end of the emperor's life include a composition with a cup, one with a falcon, and one with his grandson Shah Shuja.9

Figure-8 Jahangir stands in a window wearing a green turban and a jama embroidered with purple crocuses. A cameo hangs from ropes of pearl necklaces he fingers and in his other hand he holds a globe; below the young Jesus leans out of a similar window carrying a small cross (illustrated).

By Hashim (above),Abu'l-Hasan(below), c.1620(above),c.1610-20(below), Verso

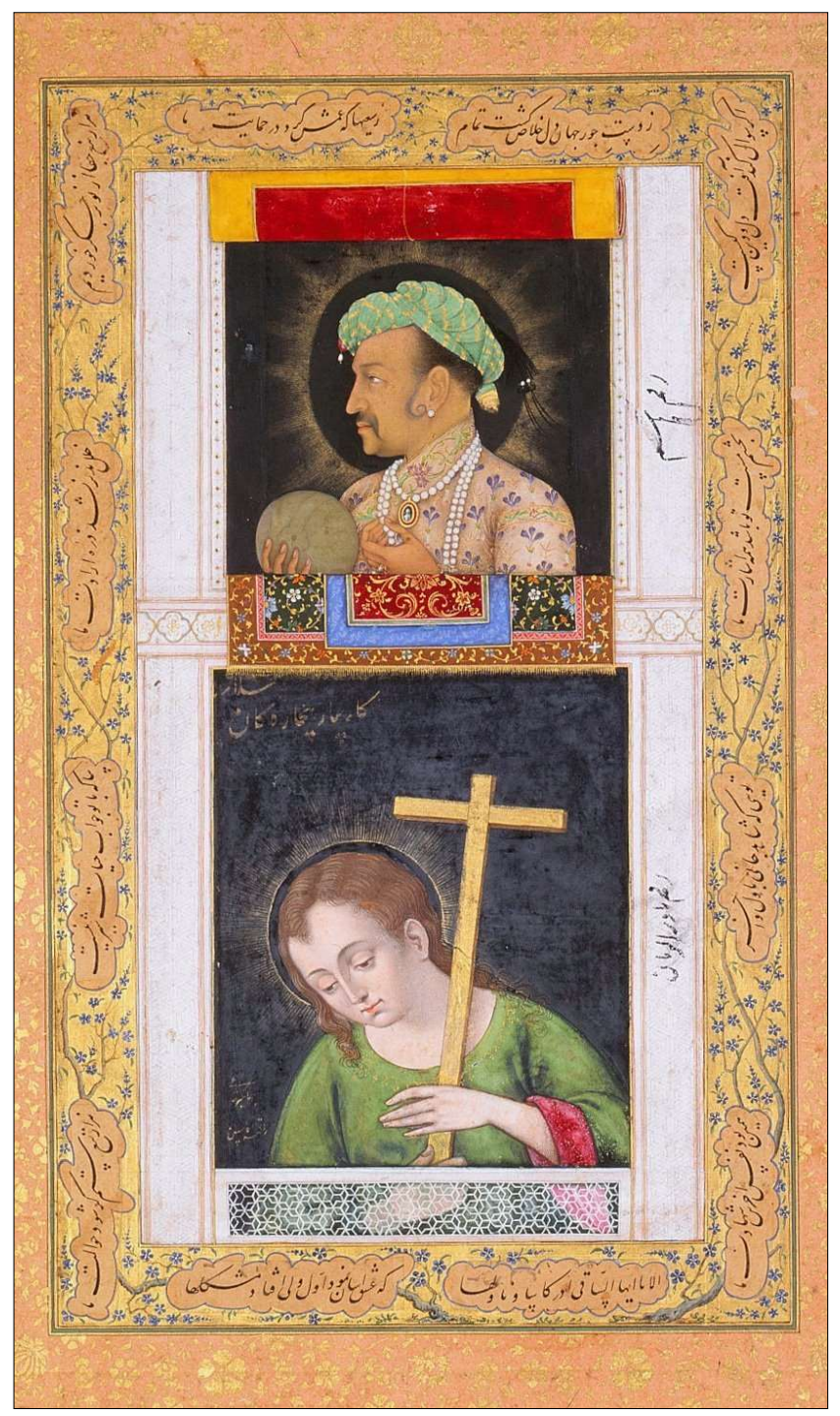

Figure-8 (edi. Linda York Leach, Mughal and other paintings from the chesterbeatty library volume-I, 1995, page-395)

Inscription: a folio number 47 is on the right margin. The inscription on the right side of the upper picture reads raqam-i has(h)im ('work of Hashim'); that for the lower picture reads raqam-i nadir-i zaman ('work of Nadir Zaman')

Borders: the miniatures are surrounded by a band of calligraphic verses against gold with blue flowering branches; the inner border is pink, the outer buff with multi-coloured flowering plants. Size: $17.1 \times 9.2 \mathrm{~cm}$, Reverse:inner border blue, outer buff with coloured flowering plants surrounding calligraphy by Mir'Ali

Library number:7A.12, Reproduced: Gascoigne, p.114, Note: Abu'l-Hasan's picture of the young Jesus is typical of painting he was doing early in the seventeenth century when European art, especially with religious themes, intrigued and stimulated him, but was not yet 
fully adapted to his own creative style. Thus, this small picture is likely to have been done as early as 1610; it was extended by Hashim about 1620 judging from the age of Jahangir as if at his daily darshan ceremony so that the rug on the rug on the window ledge extends over Abu'l-Hasan's miniature unifying the two compositions.

Jesus and Mary were Figures commonly employed in Mughal painting, and miniatures painting the court are often shown on eaves or on the tops of thrones leaning down to bless the earthly ruler. Thus, it is amusing that the Christian image here is firmly subordinated to the imperial Jahangir placed above who holds a globe to symbolize dominion.

As shown here, Hashim's miniature style is superbly precise; he was a master at painting minute details such as those of Jahangir's costume. While his abilities were limited to portraiture, his style was highly developed within a narrow range. This composition coordinates with that of the following page which is also partly by Hashim.10

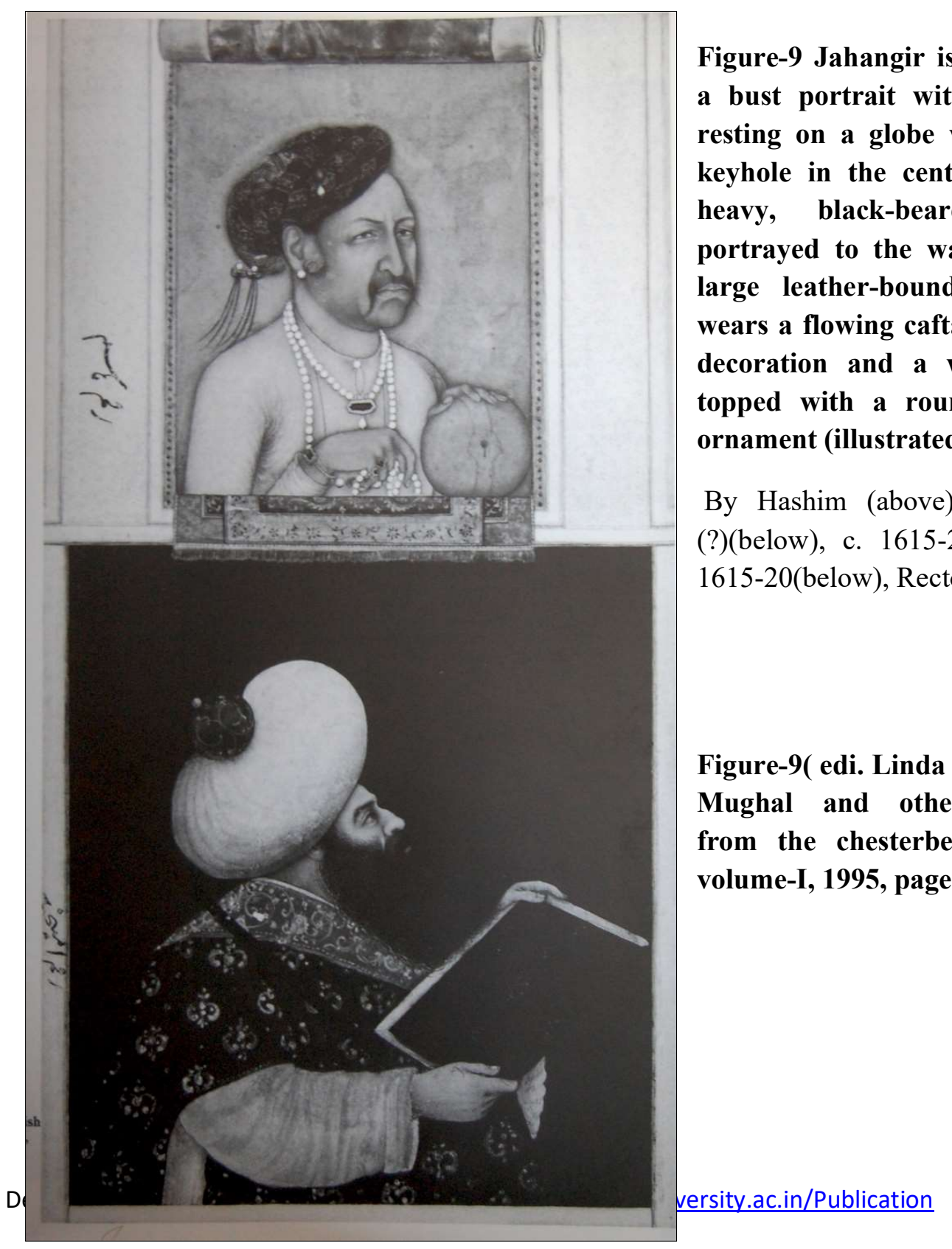

Figure-9 Jahangir is depicted in a bust portrait with one hand resting on a globe which has a keyhole in the centre; below a heavy, black-bearded Turk, portrayed to the waist, holds a large leather-bound book. He wears a flowing caftan with gold decoration and a wide turban topped with a round ball like ted).

By Hashim (above),Ami Chand (?)(below), c. 1615-20(above), c. 1615-20(below), Recto

Figure-9( edi. Linda York Leach, Mughal and other paintings from the chesterbeatty library volume-I, 1995, page-397) 
Inscriptions: inscribed on the margin with the folio number 48; on the left of the upper miniature raqam-i has (h) im ('work of Hashim'); on the left of the lower miniature miniatureraqam-iami (chand) ('work of Ami Chand'), Size 17.3x9.4cm, Reverse: inner border pink, outer border buff with multi-coloured flowering plants; verses by 'Ali al-Katib ((Mir) 'Ali the scribe). Library number:7A.13, Reproduced: Arnold and Wilkinson, pl.61.

Note: the previous pagefigure- 8 bears the folio number 47 and was once paired with page numbered 48; the two, which have matching borders, are also clearly coordinated by their compositions. The two pages, both with miniatures of Jahangir atop other subjects, have a planned relationship, but the four individual paintings were probably completed at different times.

Hashim's portrait of Jahangir on this folio seems to have been cut from a sheet of duplicate pictures (still preserved in certain instances today), or to come from a composition showing the emperor standing in the jharoka window with flanking windows on either side because the edges of additional window frames can be seen on the margins of the miniature. This unexplainably clumasy depiction is an extraordinary contrast to Hashim's other portrait of Jahangir designed to face this work. The usually precise Hashim here demonstrates a surprising lack of drawing ability and skill in modelling, probably the result of mass production.

The miniature below depicts an unidentified Turk, presumably either supposed to represent the sultan or an emissary. Visitor from Turkey were rare at the Mughal court, and in 1608 Jahangir notes that there had never been any official exchange between the two powers. At that time, he sent away a man who purported to represent the Turkish sultan; however, sir Thomas Roe mentions that a genuine ambassador did visit the court in 1615 while it was at Ajmer. A few other depictions of Turks occur in the miniatures of Jahangir's period, and it has been conjectured that these were based on European artistic prototypes rather than on actual personages. In this case the textile patterns seem more European than purely Turkish and thus the subject may have been inspired by a Western print.

The portrait is by an otherwise unknown Hindu artist called Ami Chand (?); his anonymity is interesting as Jahangir is generally understood to have been the patron of a small coterie of artist who were employed over many years and are comparatively well-known today through numerous signed or inscribed paintings.11 
Towards Excellence: An Indexed, Refereed \& Peer Reviewed Journal of Higher Education / Dr. Drashti Jaykrushna / Page 392-412

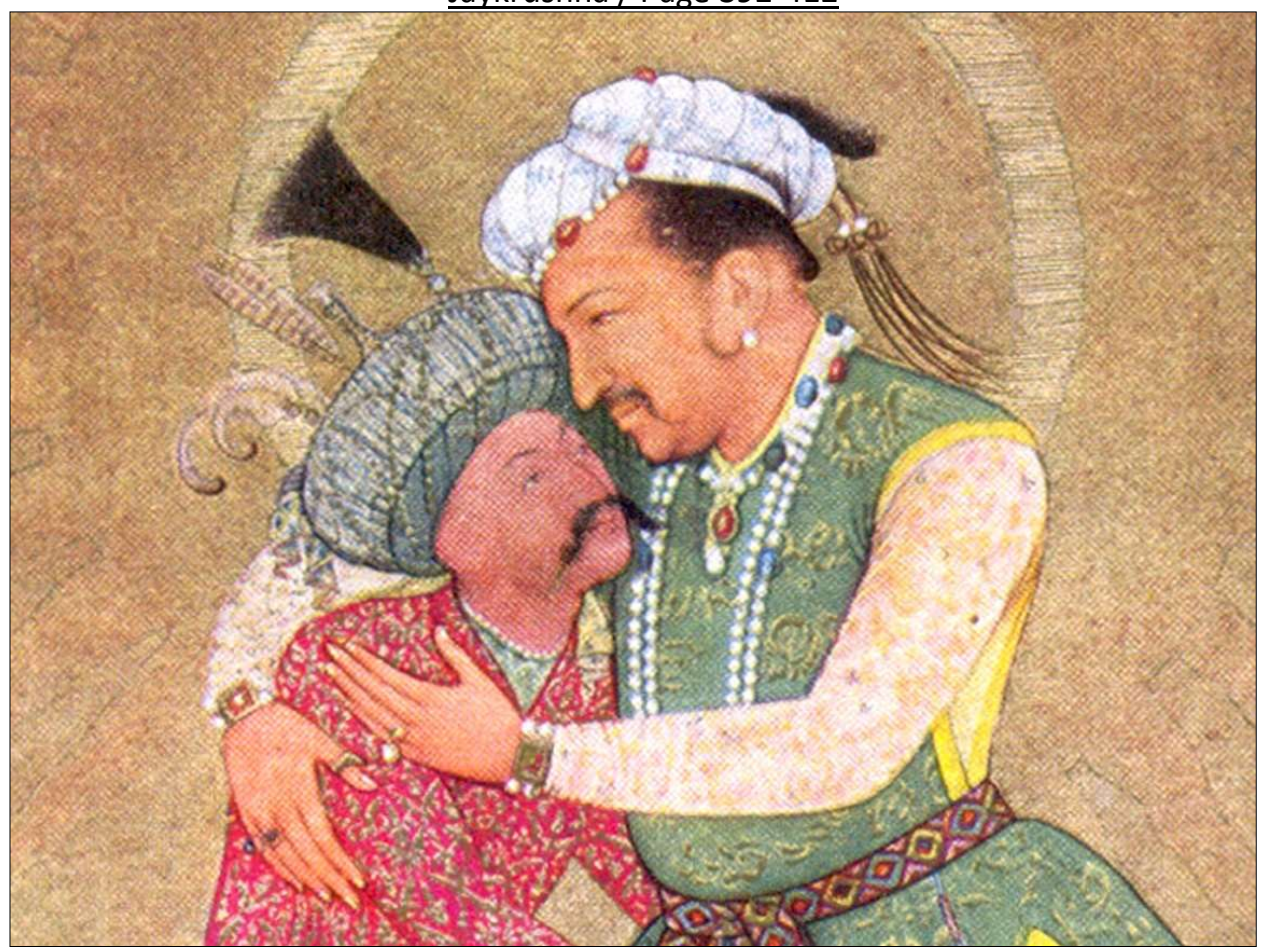

Fiure-10Sultans and Emperors of India in American collections .lalit kala Akademi.

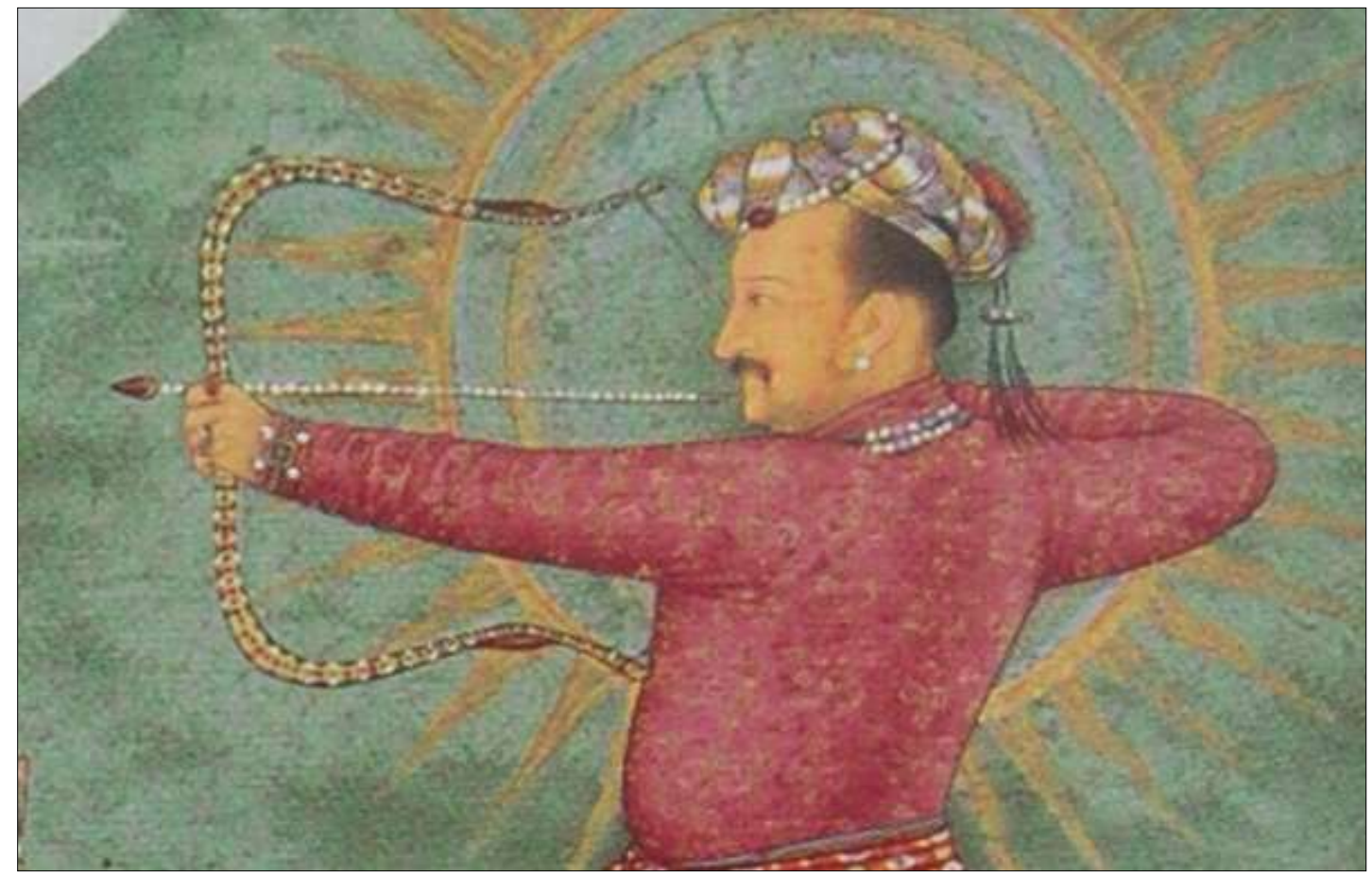

figure-11

Dec, 2020. VOL.12. ISSUE NO. $5 \quad$ https://hrdc.gujaratuniversity.ac.in/Publication 
(ed. J.pLosty and Malini Roy, "Mughal Inadia Art, Culture and Empire", 09 November 2012 - 02 April 2013, Page- 18)

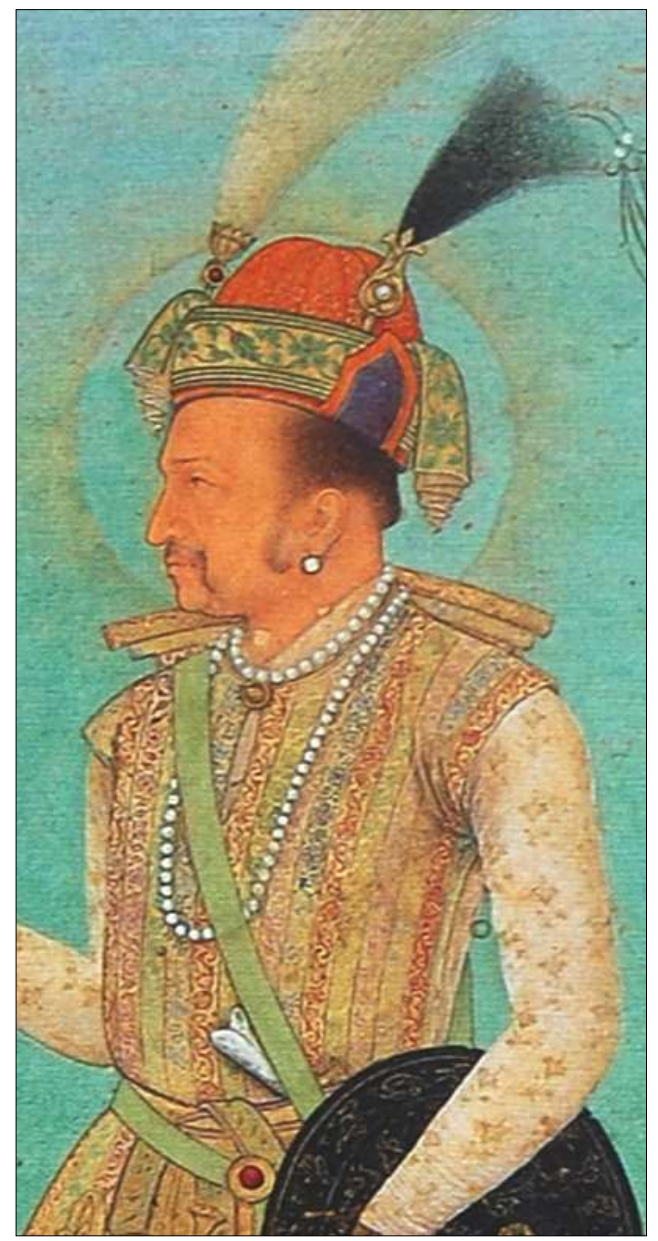

\section{figure-2.1 figure-12 Sultans and Emperors of India in American}

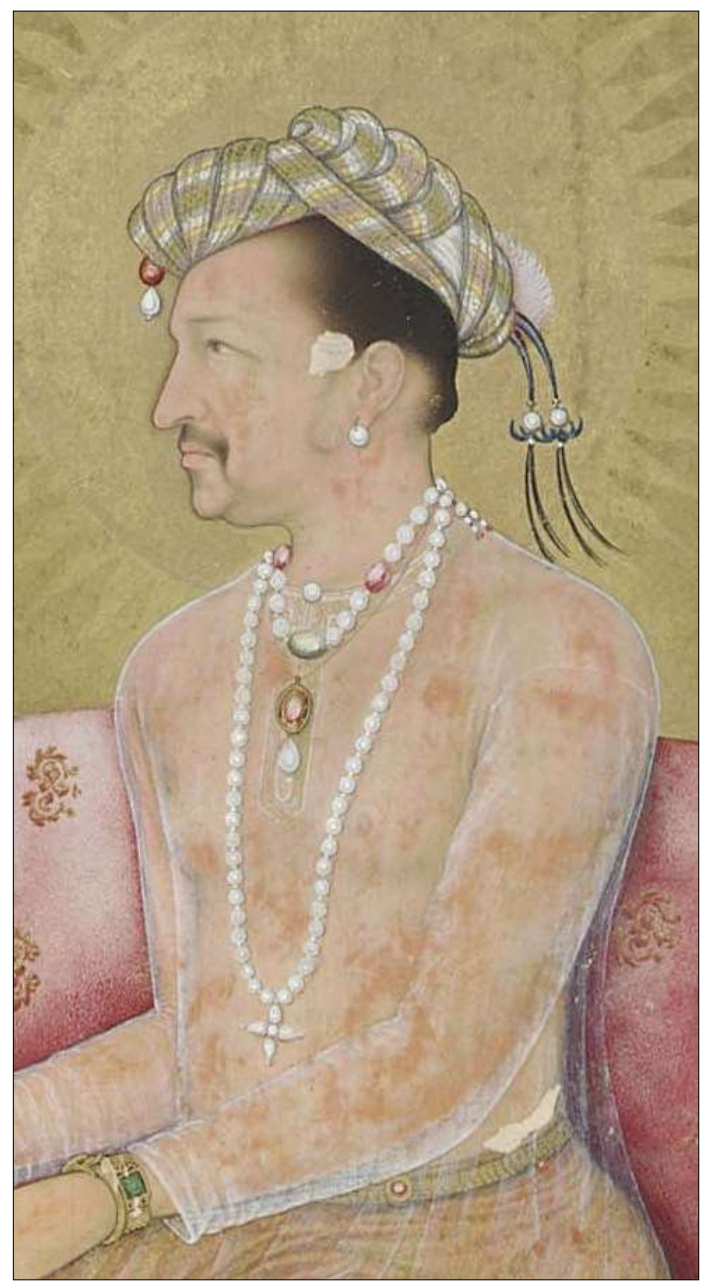

\section{collections. Lalit kala Akademie.}

The Kevorkian Album

Sometime in the late 1920s, English businessmen on home leave from Alexandria, Egypt, reputedly found an album of Indian paintings and calligraphies in a small antique shop in Scotland. Having bought it for 100 pounds, he took it to Sotheby's for evaluation, with the result that it was placed in auction (December 12, 1929, lots 101-48) and sold to Hagop Kevorkian for 10,500 pounds. In a subsequent legal battle between Kevorkian and the auction house, the authenticity of the works was questioned but upheld, and in 1939 five pages were sold to the freer Gallery. Four additional pages followed in 1948, and the remaining thirtyseven illustrated folios, covers, and four illuminated pages were purchased by the Metropolitan Museum in New York. 
The album -since termed the Kevorkian Album - consists chiefly of portraits of the Mughal emperors and nobles, animal studies, and calligraphies. These are surrounded by elaborate floral borders typical of the Shah Jahan period, and one of the illuminated rosettes in New York bears an ornamental inscription in homage to that ruler.

Several of the illustrations in the album are known in other versions (figure-2.1), and questions arise as to which of these -if any -is the original. And what relationship (in terms of date, hand, and motivation) exists among the copies. Most of the works have an inscribed attribution to a major Mughal artist;

A second comparison helps us to see that this is by no means an isolated example. Jahangir Shooting the Head of Malik Ambar (c5 figure-11) is an ichnographically superb portrait. It is inscribed to Abu'l Hasan, Nadir-al-zaman, but when we compare it to Jahangir Embracing Shah Abbas (figure-10), from the Leningrad Album, signed by the same artist, the qualitative differences are even more apparent. (figure-10), the emperor's garment is carefully modelled to reveal how it covers the body beneath, and a sense of substantiality and physical presence is created. In Jahangir Shooting the Head of Malik Ambar, there is no concession to the play of light on the surface of the emperor's robe, nor does the cloth seem to enfold any forms beneath it; it is completely flat, as if cut from wallpaper. Furthermore, the face lacks the sense of personality found in catalogue number (figure-10), and this is the focus of Abu'l Hasan's interest in all his authentic works. A close correspondence seems to exist between a major group of Kevorkian Album pages, such as the two just discussed, and painting made in the early nineteenth century for the imperial court at Delhi. It seems very likely, therefore, that several folios are late copies of imperial album pages of the first half of the seventeenth century.

A more difficult judgment is demanded by Jahangir Holding a Globe (figure-2.1). Compared to Jahangir Embracing Shah Abbas, there is now little difference in terms of technical skill. The modelling of cloth and flesh, or the drawing of the jewels, is meticulous and precise in both illustrations. If we examine Jahangir's helmet (see detailfigure-2.1) and Shah Abbas's turban (see detail figure-10), however, we find that the quickness and aliveness of drawing in the latter work is absent in the Kevorkian Album page, where precision has replaced vivacity. The face of the emperor is harder, without the extraordinary immediacy found in either of the freer portraits accepted here as by Abu'l Hasan (figure-10 and 12). These characteristics are typical of one major strand of Shah Jahan period painting, and the work seems a superb example of Mughal portraiture of about 1650. It does not relate to what we know of Abu'l Hasan, however, except iconographically, but it may well be a copy of an earlier allegorical portrait. The Late Shah Jahan Album, made about 1650, contains a series of illustrations (again almost completely portrait) in exactly this style, some of which are copies of known early works.

Several Kevorkian Album illustrations (figure- 11) are based on known earlier porotypes in the Minto Album, a completely Shah Jahan period assemblage. Other related albums containing both early and late works are known. The Wantage Album in the Victoria and Albert Museum, London, may well have originally been joined the Kevorkian Album, and 
another volume is in the city Palace Museum, Jaipur. The activity of copying as itself accepted and, indeed, necessary with the Mughal context. As we noted earlier, Akbar ordered his nobles to make copies of the illustrated Razm-nama manuscript, which he commissioned in 1582, while sir Thomas Roe recorded in his diaries that Jahangir ordered six of his artists to make copies of a painting owned by Roe. And it is certain that the various presentation portraits that Jahangir (in the Tuzuk-i-Jahangiri) noted giving out were probably massproduced copirs rather than unique works. It is possible that whole albums of copies were later formed as presentation items, a custom continued with the photograph albums formed in the nineteenth century. 12 . 


\section{References}

1. http://blog.artoflegendindia.com/2010/12/mughal-paintings-imperial-atelier-of.html

2. http://historytodaymagazine.blogspot.in/2010_03_01_archive.html

3. http://guity-novin.blogspot.in/2010/02/history-of-graphic-design-art-of.html

4. Edi. Stuart Cary Welch, Annemarie Schimmel, Marie L. Swietochowski, Wheeler M. Thackston, the Emperors' Album Images of Mughal India, 1988, page- 104,107

5. edi. Linda York Leach, Mughal and other paintings from the chesterbeatty library volume-I, 1995, page-388,389.

6. edi. Linda York Leach, Mughal and other paintings from the chesterbeatty library volume-I, 1995, page-388,389.

7. edi. Linda York Leach, Mughal and other paintings from the chesterbeatty library volume-I, 1995, page-451.

8. edi. Linda York Leach, Mughal and other paintings from the chesterbeatty library volume-I, 1995, page-451,452,453.

9. edi. Linda York Leach, Mughal and other paintings from the chesterbeatty library volume-I, 1995, page-453,454.

10. edi. Linda York Leach, Mughal and other paintings from the chesterbeatty library volume-I, 1995, page-396.

11. edi. Linda York Leach, Mughal and other paintings from the chesterbeatty library volume-I, 1995, page-396,398.

12. ed.Milo Cleveland Beach, The Imperial Image Paintings for the Mughal Court, 1981january 10,1982,page-177,178,179,182,183.

\section{Dr.DrashtiJaykrushna}

Visiting faculty

Department of Indian culture (Indology)

Gujarat University, Ahmedabad, Gujarat, India 